\title{
Protection of Aluminum Foils against Environmental Corrosion with Graphene-Based Coatings
}

\author{
George Paterakis ${ }^{1,2}$, George Anagnostopoulos ${ }^{1,{ }^{*}}$, Labrini Sygellou ${ }^{1}$ and Costas Galiotis ${ }^{1,2,}$ \\ ${ }^{1}$ Institute of Chemical Engineering Sciences, Foundation for Research and Technology - Hellas (FORTH/ ICE-HT), \\ Patras 265 04, Greece \\ ${ }^{2}$ Department of Chemical Engineering, University of Patras, Patras 26504, Greece
}

\begin{abstract}
Commercial aluminum foils were coated by graphene oxide, and its functionalized derivatives and the corrosion performance of the coated specimens were examined in acidic conditions (lithium perchlorate and sulfuric acid). Electrochemical experiments have shown that all graphene oxide-coated specimens provided up to $96 \%$ corrosion inhibition efficiency with a corresponding lower corrosion rate compared to the bare aluminum foil. Our results clearly show that graphene-related materials offer viable alternatives for the protection of aluminum, and this opens up a number of possibilities for its use in a number of commercial applications.
\end{abstract}

Received on 15-06-2021

Accepted on 20-09-2021

Published on 28-09-2021

Keywords: Aluminum, functionalized graphene oxide, electrophoretically deposited coatings, polarization, and potentiostat measurements.

\section{INTRODUCTION}

One of the major challenges of the modern world is to find a way to inhibit the process of metal corrosion, a problem that is triggered by environmental factors such as the presence of oxygen [1], water [2], ultraviolet (UV) [3] and electrolytes [4]. According to the IMPACT study, released in 2016 by NACE International-The Worldwide Corrosion Authority [5], the global cost of corrosion is estimated to be US $\$ 2.5$ trillion. Therefore, innovative and long-lasting solutions are needed to overcome the effects of corrosion on the metallic infrastructure of everyday life, from pipelines to bridges and from transportation to material storage.

Up to now, several techniques have been employed for the protection/prevention against corrosion, such as passivation, cathodic protection, coating coverage [6-9], etc. Regarding the latter, corrosion protection involves the shielding of the metal surface by the use of a protective coating made of materials such as inert metals or organic layers (polymers) $[10,11]$. The main requirements for corrosion-resistant coatings are high service life even under extreme environmental conditions. However, there are limitations on

"Institute of Chemical Engineering Sciences, Foundation for Research and Technology - Hellas (FORTH/ ICE-HT), Patras 265 04, Greece,

E-mail: george.anagnostopoulos@iceht.forth.gr, c.galiotis@iceht.forth.gr their performance, which has to do with the alteration of the physical properties of the metal substrate $[8,12]$ as well as their impact on human life and the environment [4, 13].

Over the last few years, the usage of carbon-based materials, either alone or encapsulated in polymer matrices, as anticorrosion coatings, for metal surfaces has been studied [14, 15]. Besides being the thinnest and strongest known material, graphene can be employed in nano-coatings for anticorrosion applications due to its chemical stability and the very low molecular permeability even for He atoms [13, 1618]. The introduction of graphene, as well its derivative such as graphene oxide (GO) and/or reduced graphene oxide ( $r \mathrm{GO}$ ), seems to open a whole new perspective in the field of anti-corrosion applications [13, 18-21].

Recently, the pioneering work of Chen et al. [8] showed the ability of graphene, produced by chemical vapor deposition (CVD), to act as a passivation layer protecting metallic substrates such as copper $(\mathrm{Cu})$ or copper/nickel $(\mathrm{Ni})$ alloys against oxidizing gas and liquid solutions. Moreover, Prasai et al. [12] demonstrated that CVD graphene, either grown directly on metal substrates or mechanically transferred to them, can effectively prevent short-term corrosion. While Kirkland et al. [22] and Raman et al. [23] have confirmed the potential for graphene coatings to serve as a barrier to 
aggressive aqueous salt solutions on $\mathrm{Ni}$ and $\mathrm{Cu}$. However, as is reported by Schriver et al. [24] and Zhou et al. [25], the presence of defects, as well as grain boundaries in the CVD graphene membrane, can act as promoters of corrosion (by atmospheric oxygen and water agents) in the long term (> 6 months), even at ambient temperatures.

As established in work mentioned above, corrosion inhibition can be further enhanced if the deposited graphene has higher purity to achieve a more homogeneous coating structure, especially in aluminum (Al) surfaces, where galvanic corrosion is promoted [26]. Immersion tests have revealed that the metal corrosion is mainly due to graphene defects [27].

By sealing those defects with poly-pyrrole using electrodeposition, the produced hybrid coating, after immersion in a salt solution for $65 \mathrm{~h}$, not only cover the small areas of bare copper at the defect sites of graphene but also act as a passive layer counteracting the diffusion of corrosive species and markedly reducing the corrosion rate of the substrate. On the other hand, by modifying the hydrophobic graphene surface, it was found that the anti-corrosion property of Al alloy is improved [28, 29].

Based on the above, an effective coating against corrosion ought to have the ability to be in intimate contact with the metallic substrate. At the same time, to exploit graphene's anti-corrosion performance, it is necessary to apply an effective and more homogeneous deposition method so that all kinds of metal substrates can easily be coated.
Electrophoretic deposition (EPD) is currently the most common technique applied for coating metals using graphene derivatives, such as $\mathrm{GO}$ and $\mathrm{rGO}$ [30-32] since it has the ability to form a relatively dense and homogeneous packed layer on any electrically conductive surface [33].

Particularly, it was found by tailoring graphene coating in tandem with EPD, the corrosion rate of $\mathrm{Cu}$ was reduced by 10 times [34]. Similarly, a crack-free GO-polymer composite coating of $45 \mathrm{~nm}$ thickness has been found to provide shielding under harsh environmental conditions [33]. At the same time, mild steel coupons coated with nickel/graphene hybrid film showed excellent anti-corrosion performance, mechanical durability, and long-term stability [35]. Also, it was found that GO, due to its high functionality, enhances the EPD process and facilitates the formation of an underlying anti-corrosive layer, for instance, on mild carbon steel [36].

Herein, we present a comprehensive experimental investigation of the protection of Al foils, the most accepted cathode current collector for Lithium-ion batteries (LIBs), in corrosive environments using graphene-related materials (GRMs) [37]. We employed easy-to-apply conformal thin coatings (up to $6 \mathrm{~nm}$ ) to Al foils of graphene oxide (GO, dipcoating, and EPD), functionalized lithium-graphene oxide (GO-Li), and electrochemically reduced forms of them (erGO, erGO-Li). With a custom-made galvanic cell potentiostatic and potentiodynamic polarization, we experimentally evaluated the degree of protection against corrosion of commercial Al foils coated with the GRMs as above.

Table 1: The Materials as well the Conditions of the Measurements Employed for the Evaluation of Anti-Corrosion Performance of the Examined GRMs

\begin{tabular}{|c|c|}
\hline Materials & Conditions/Synthesis/Preparation \\
\hline $\begin{array}{l}\text { Commercial graphene-based } \\
\text { coatings on Al foils }\end{array}$ & Specimens $\mathrm{S}_{\mathrm{A}}, \mathrm{S}_{\mathrm{B}}$ and $\mathrm{S}_{\mathrm{c}}$ were all commercial specimens that can be purchased via the internet. \\
\hline \multirow[t]{3}{*}{$\begin{array}{l}\text { Graphene-based coatings produced } \\
\text { in this work }\end{array}$} & $\begin{array}{l}\text { Synthesis of graphene oxide (GO) } \\
\text { The GO is synthesized from natural graphite flakes (NGS Naturgraphit } \mathrm{GmbH} \text {, Germany) by a two-step oxidation } \\
\text { process, based on Kovtyukhova et al. method [38]. The steps followed are presented below: } \\
\text { - } 10 \mathrm{gr} \text { of natural graphite flakes are added in } 75 \mathrm{ml} \text { concentrated sulfuric acid }\left(\mathrm{H}_{2} \mathrm{SO}_{4} 96 \%\right) \text { in a flask. The } \\
\text { flask is placed in a bath and heated at } 80{ }^{\circ} \mathrm{C} \text {. } \\
5 \mathrm{~g} \text { potassium persulfate }\left(\mathrm{K}_{2} \mathrm{~S}_{2} \mathrm{O}_{8}\right) \text { and } 5 \mathrm{~g} \text { phosphorus pentoxide }\left(\mathrm{P}_{2} \mathrm{O}_{5}\right) \text { are added to the solution. The } \\
\text { mixture is stirred for } 1 \mathrm{~h} \text { at this temperature and then is allowed to } \mathrm{cool} \text { at room temperature for a period of } 5 \\
\mathrm{~h} \text {. The reaction is terminated by carefully adding deionized water (DW), followed by several steps of vacuum } \\
\text { filtration with DW and drying. } \\
\text { - The oxidized graphite is then subjected to oxidation. } \\
\text { - The powder is stirred continuously into a flask with } 220 \mathrm{ml} \mathrm{H} 2 \mathrm{SO} 496 \% \text {, in a water bath under } 20{ }^{\circ} \mathrm{C} \text {. } \\
\text { - } 26.7 \mathrm{~g} \text { potassium permanganate }\left(\mathrm{KMnO}_{4}\right) \text { was added to the mixture. } \\
\text { - The mixture is heated to } 40{ }^{\circ} \mathrm{C} \text { for } 2 \mathrm{~h} \text {, where } 1.8 \text { liters } \mathrm{DW} \text { is added carefully, followed by } 22 \mathrm{ml} \text { hydrogen } \\
\text { peroxide }\left(\mathrm{H}_{2} \mathrm{O}_{2} 30 \%\right) \text {. } \\
\text { Filtering and washing with } 1: 10 \mathrm{HCl} \text { solution in order to remove most of the metal ions. The solid product of } \\
\text { this process is re-dispersed in } \mathrm{DW} \text { and subjected to dialysis until the pH is naturalized. } \\
\text { Finally, single and few layers of } \mathrm{GO} \text { are collected by a combination of ultrasonication and centrifugation steps. }\end{array}$ \\
\hline & $\begin{array}{l}\text { Synthesis of lithium functionalized graphene oxide (GO- } \mathrm{Li} \text { ) } \\
\text { For the synthesis of } \mathrm{Li}-\mathrm{GO}, 100 \mathrm{mg} \text { of } \mathrm{Li}_{2} \mathrm{CO}_{3} \text { (Sigma-Aldric) is added in a baker with } 100 \mathrm{ml} \text { of } \mathrm{GO} \text { dispersion }(1.5 \\
\mathrm{mg} / \mathrm{ml} \text { ). The mixture is left to react for } 2 \text { hours under stirring at } \mathrm{RT} \text {. Finally, the by-products of the reaction are removed } \\
\text { by repeated steps of centrifugation and re-dispersion in DW. }\end{array}$ \\
\hline & $\begin{array}{l}\text { Samples preparation } \\
\text { GO and GO-Li were coated over aluminum foils by dip coating of corresponding dispersion of } 0.5 \mathrm{mg} / \mathrm{ml} \text { of each of them. } \\
\text { After the process, the samples were left to dry under } \mathrm{N}_{2} \text { flow for several hours. For the electrochemically reduced } \\
\text { samples }\end{array}$ \\
\hline
\end{tabular}


According to the results shown in the subsequent sections, the functionalized GOs provided a corrosion inhibition efficiency of up to $90 \%$ in aggressive environments such as lithium perchlorate $\left(\mathrm{LiClO}_{4}-1 \mathrm{M}\right)$, which simulates the conditions of LIBs, and sulfuric acid $\left(\mathrm{H}_{2} \mathrm{SO}_{4}-0.5 \mathrm{M}\right)$. In contrast, the corrosion rate is almost reduced by order of magnitude. Moreover, the post-electrochemically reduced GOs, provided higher corrosion protection. Finally, by comparing their performance with the commercial GRMs coated specimens, it is found that the latter is inferior not only in the level of coverage and uniformity but also in the degree of corrosion protection, indicating that the corresponding market is filled with products of questionable quality and performance that need to be evaluated.

\section{MATERIALS AND METHODS}

The materials and methods [38, 39] used in this work are described in Table 1.

\section{EXPERIMENTAL}

The characterization techniques employed for the performance evaluation of the GRM coatings are depicted in Table 2.

\section{RESULTS AND DISCUSSION}

\subsection{Characterization of Commercial Al Foils Coated with GRMs}

Commercial Al foils coated with $\mathrm{GRMs}\left(\mathrm{S}_{\mathrm{A}}, \mathrm{S}_{\mathrm{B}}\right.$, and $\left.\mathrm{S}_{\mathrm{C}}\right)$ were studied using Raman spectroscopy. In Figure 2, the obtained Raman spectra for the examined samples are presented. Judging from the characteristics values of the Raman spectra (2D/G intensity ratio and the shape of the $2 D$ peak), we conclude that the GNP used in this work have layers $n>10$, so they are classified as nano-graphites [40]. Furthermore, the Sc sample seems to show the lowest degree of peeling of the graphitic structures, as the width and shape of the 2D peak bear greater similarity to the corresponding graphite peak as compared to the other two samples. Also, a D peak $\left(\sim 1300 \mathrm{~cm}^{-1}\right)$ is present in all samples, indicating defects in the hexagonal graphene network. These defects can be attributed either to edges of broken nano-graphite particles and/or due to potential mild chemical treatment [41].

The strong presence of the Al2p peak in the aluminum XPS spectra indicates that the coating in all samples is either very thin or exhibits vacancies since the penetration depth of the XPS method is only $10 \mathrm{~nm}$ (Figure S3). Initially, the analysis

Table 2: The Methods and their Corresponding Conditions Followed for the GRM Anti-Corrosion Coatings Examined

\begin{tabular}{|c|c|c|}
\hline Method & Acronym & Conditions \\
\hline $\begin{array}{l}\text { X-ray photoelectron } \\
\text { spectroscopy }\end{array}$ & XPS & $\begin{array}{l}\text { The photoemission experiments were carried out in an ultra-high vacuum system (UHV) which consists of a fast } \\
\text { entry specimen assembly, a sample preparation and an analysis chamber equipped with a dual anode (Al/Mg) X- } \\
\text { Ray gun and an LH10 electron analyzer. The base pressure in both chambers was } 1 \times 10^{-9} \text { mbar. } \\
\text { Unmonochromatized MgKa line at } 1253.6 \mathrm{eV} \text { and an analyzer pass energy of } 36 \mathrm{eV} \text {, giving a full width at half } \\
\text { maximum (FWHM) of } 0.9 \mathrm{eV} \text { for the Au } 4 \mathrm{f} 7 / 2 \text { peak, were used in all XPS measurements. The XPS core level } \\
\text { spectra were analyzed using a fitting routine, which can decompose each spectrum into individual mixed } \\
\text { Gaussian-Lorentzian peaks after a Shirley background subtraction. The sample was mounted onto a Si substrate } \\
\text { with dimensions } 1.5 \times 1.5 \mathrm{~cm}^{2} \text {. }\end{array}$ \\
\hline Raman spectrsocpy & Raman & $\begin{array}{l}\text { Spectra were taken with a } 514 \mathrm{~nm}(2.41 \mathrm{eV}) \text { laser using a MicroRaman (InVia Reflex, Rensihaw, UK) set-up. The } \\
\text { laser power was kept below } 1.5 \mathrm{~mW} \text { on the sample to avoid laser induced local heating, while an Olympus } \\
\text { MPLN100x objective }(\mathrm{NA}=0.90) \text { was used to focus the beam on the samples. }\end{array}$ \\
\hline $\begin{array}{l}\text { Scanning Electron } \\
\text { Microscopy }\end{array}$ & SEM & $\begin{array}{l}\text { The surface analysis of the samples were studied by using Field-Emission Scanning Electron Microscopy } \\
\text { (FESEM, Zeiss SUPRA } 35 \text { VP). }\end{array}$ \\
\hline $\begin{array}{l}\text { Atomic Force } \\
\text { Microscopy }\end{array}$ & AFM & $\begin{array}{l}\text { AFM images were collected by a contact mode (Bruker, Dimension-Icon). Images were obtained using } \\
\text { ScanAsyst-Air probes (silicon tips on silicon nitride cantilever, Bruker) with } 0.4 \mathrm{~N} \mathrm{~m}^{-1} \text { nominal spring constant of } \\
\text { the cantilever. }\end{array}$ \\
\hline $\begin{array}{c}\text { UV-vis and IR } \\
\text { spectroscopy using the } \\
\text { Attenuated } \\
\text { Reflectance Technique } \\
\text { (ATR) }\end{array}$ & UV-vis/IR & $\begin{array}{l}\text { UV-Vis absorbency spectra were recorded using a Hitachi U- } 3000 \text { reverse optics spectrophotometer, while the } \\
\text { IR spectra were measured using Attenuated Reflectance Technique (ATR) of Bruker Equinox FTIR } \\
\text { spectrometer. }\end{array}$ \\
\hline X-ray Diffraction & XRD & $\begin{array}{l}\text { XRD measurements were obtained by Bruker D8 advance XRD diffractometer with CuKa radiation }(\lambda=1.5406 \AA \text {, } \\
40 \mathrm{kV}, 40 \mathrm{~mA}) \text {. }\end{array}$ \\
\hline $\begin{array}{l}\text { Corrosion } \\
\text { measurements }\end{array}$ & Corrosion & $\begin{array}{l}\text { The electrochemical corrosion of the samples was separately measured using potentiostatic and } \\
\text { potentiodynamic polarization methods using three-electrode cells (Figure } \mathrm{S1} \text { ). The electrochemical cell was } \\
\text { consisted of a silver/silver chloride }(\mathrm{Ag} / \mathrm{AgCl}, \mathrm{KCl} 3 \mathrm{M} \text { ) electrode and a platinum sheet as reference and counter } \\
\text { electrodes, respectively. The sample to be tested was sealed on the base of the cell to make corrosion possible } \\
\text { only on the coated side with an active area of } 1 \mathrm{~cm}^{2} \text {, acted as the working electrode. All the samples were tested } \\
\text { in } 2 \text { different electrolyte environments, namely } \\
\text { (i) } 0.5 \mathrm{M} \text { sulfuric acid }\left(\mathrm{H}_{2} \mathrm{SO}_{4} \text {, Sigma Ardrich) aqueous solution and }\right. \\
\text { (ii) } 1 \mathrm{M} \text { lithium perchlorate }(\mathrm{LiClO} \text {, Sigma Ardrich) in } 1: 1(\mathrm{w} / \mathrm{w}) \text { mixed solvent of ethylene carbonate (EC, } \\
99.95 \% \text {, Sigma Ardrich) and } 1,2 \text {-dimethoxyethane (DME, } 99.5 \% \text {, Sigma Ardrich). } \\
\text { The corrosion measurements were performed on each sample, first by recording the open circuit potential (OCP) } \\
\text { during a stabilization period of } 30 \text { min, followed by potentiodynamic polarization measurements at a scan rate of } \\
0.3 \mathrm{mV} / \mathrm{s} \text { within a scan range of } \pm 250 \mathrm{mV} \text { vs. OCP. }\end{array}$ \\
\hline
\end{tabular}


(a)

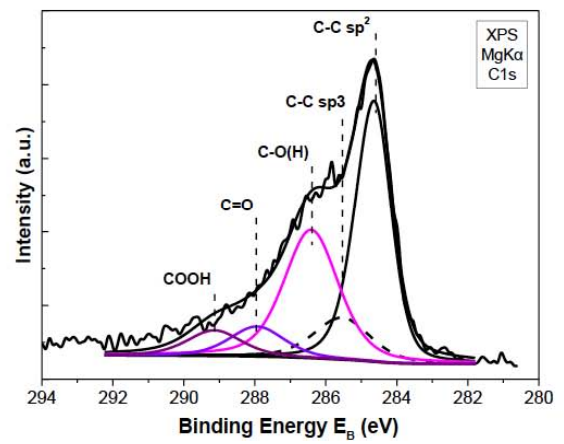

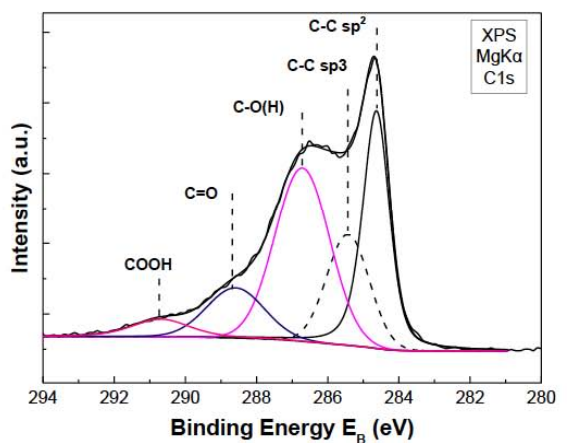

(b)

(c)

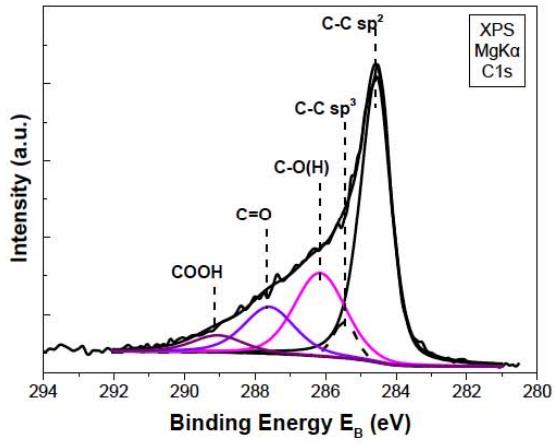

Figure 1: Deconvoluted C1s peak of (a) $S_{A}$, (b) $S_{B}$ and (c) $S_{C}$.

of the Al2p peak for each sample revealed that all three had the presence of aluminum oxide $\left(\mathrm{Al}_{2} \mathrm{O}_{3}\right)$ (Figure S3), with a characteristic peak at $76 \mathrm{eV}$. In addition, the analysis of the C1s peak spectra for each sample (Figure 1) shows that $S_{B}$ and $S_{C}$ have a higher oxidation rate than $S_{A}$. In general, the presence of oxygen in the graphene coatings of the samples appears either circumferentially forming carboxyl groups $(-\mathrm{COOH})$ or on the surface of the matrix forming $\mathrm{C}=\mathrm{O}, \mathrm{C}-\mathrm{OH}$ bonds. Based on the images obtained by optical microscopy (OM) (Figure S4), it is assumed that the surface coverage of the samples examined is incomplete. Since graphene layers with thickness lower than 3-5 sheets are quite difficult to be traced by $\mathrm{OM}$, especially when the substrate's surface is rough, the degree of coverage of Al foils with GRMs was examined in detail by spatial Raman mapping.

In Figure 2, Raman mapping based on the intensity of the $G$ peak is shown. As it is evident, all samples investigated show vacancies (black-colored areas). These areas, where the intensity of the G-peak is zero, correspond to the areas where the aluminum surface (substrate) is strongly (a)
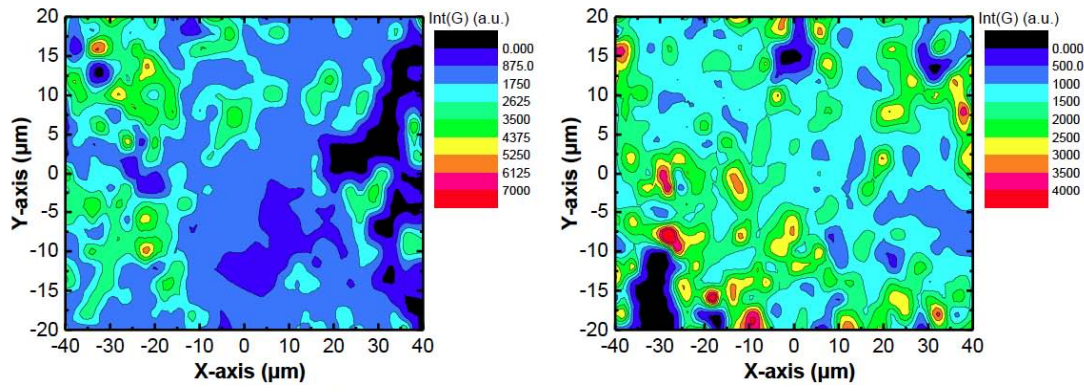

(b)

c)

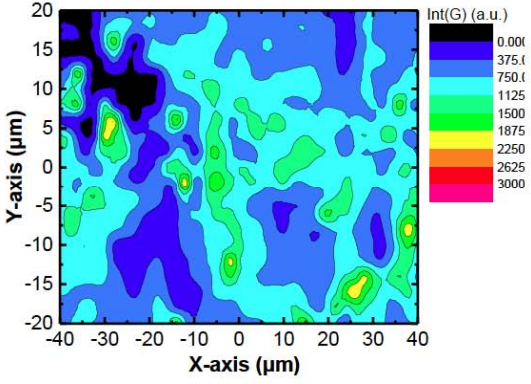

Figure 2: Surface Raman maps of (a) $S_{A},\left(\right.$ b) $S_{B}$ and (c) $S_{C}$ based on the intensity of the $G$ peak. 
distinguished by optical microscopy. Similarly, by employing Scanning Electron Microscopy (SEM) (Figure S5) and Atomic Force Microscopy (AFM) (Figure S6), we provide further confirmation of the incomplete coverage of all commercial $\mathrm{Al}$ foils samples by the nano-graphite coatings.

Finally, a quantitative analysis based on the Raman maps yields a degree of coverage of $70 \%, 78 \%$, and $87 \%$ for the $\mathrm{S}_{\mathrm{A}}, \mathrm{S}_{\mathrm{B}}$ by, and $\mathrm{S}_{\mathrm{C}}$ samples, respectively. It is worth noting here that the coating surface roughness was uneven at each examined sample material. Both SEM and AFM images show several folds of the nano-graphitic structures, which appeared to have insufficient contact with the aluminum surface. Thus, there are vacant areas, which can act as charge movement blockers within the aluminum foils.

For further investigation of the structure of the commercially available Al foils coated with GRMs, a comparison is made using bare $\mathrm{Al}$ foil in tandem with X-ray diffraction (XRD). As can be seen in Figure S7, the typical graphite peak at $26^{\circ}$ is observed in all coated samples, while their corresponding peak intensities of crystalline aluminum planes are variable among the specimens examined, attributed to the crystalline structure of the foils [42].

\subsection{Characterization of Prototype Al Foils Coated with Graphene Oxide-Based Coatings}

Following the characterization of commercially available samples, we have produced prototype Al foils coated with GO and rGO and their derivatives modified with Li. The XPS maps (Figure 3a) provide evidence for the presence of epoxides (C-O-C) and hydroxyls $(-\mathrm{OH})$, usually appeared in the main structure of the matrix, as well as carboxyl groups ($\mathrm{COOH}$ ) detected at the edges [43]. It is worth mentioning that the corresponding $\mathrm{sp}^{3}$ hybridization increases due to the introduction of the above groups and the simultaneous reduction of $C=C$ [44]. Subsequently, after the chemical modification of $\mathrm{GO}$ with $\mathrm{Li}$, the GO-Li system was also characterized by XPS, and the presence of Li1s peak of lithium at $55 \mathrm{eV}$ was verified (Figure $3 \mathbf{b}$ ).

Both GO and GO-Li were evaluated using UV-vis spectroscopy and Attenuated Reflectance IR (ATR) spectroscopy (Figure 3c). The UV-vis spectra show a shift of the GO-Li spectrum relative to that of GO by $8 \mathrm{~nm}$. The peak shown at $232 \mathrm{~nm}$ for GO (240 nm for GO-Li) is attributed to the $\pi-\pi{ }^{*}$ transitions appearing in the $C=C$ bonds of the lattice grid, while the second peak at $\sim 300 \mathrm{~nm}$ is due mainly to the $n-\pi{ }^{*}$ transitions of the $C=O$ bonds [45]. The above shift has been observed in GO suspensions that had undergone different reduction levels, during which part of the oxygen groups had been removed [44].

Similar behavior is observed in the ATR spectra (Figure 3c), where variations occur between the samples in a series of peaks: $1730 \mathrm{~cm}^{-1}(\mathrm{C}=\mathrm{O}), 1625 \mathrm{~cm}^{-1}(\mathrm{C}=\mathrm{C}), 1380 \mathrm{~cm}^{-1}(\mathrm{O}-$ $\mathrm{H})$ and $1080 \mathrm{~cm}^{-1}$ (C-O) [46]. In Figure $\mathbf{S 8}$ characteristic Raman spectra for GO, rGO, GO-Li, and rGO-Li are shown. By comparing the spectra of pristine materials and those after reduction, certain differences are evident; the ratio of the intensities of $D\left(\sim 1350 \mathrm{~cm}^{-1}\right)$ to $G\left(\sim 1580 \mathrm{~cm}^{-1}\right)$ peaks appears to increase [47] (Table 3), while the intensity of 2D $\left(\sim 2700 \mathrm{~cm}^{-1}\right)$ peak is increased as the reduction takes place [48]. As for the coating thickness employed was found to vary between 4-6 $\mathrm{nm}$ according to the AFM technique (Figure S9). (a)

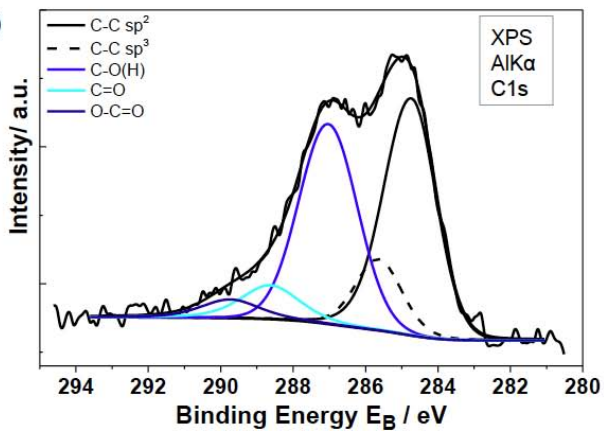

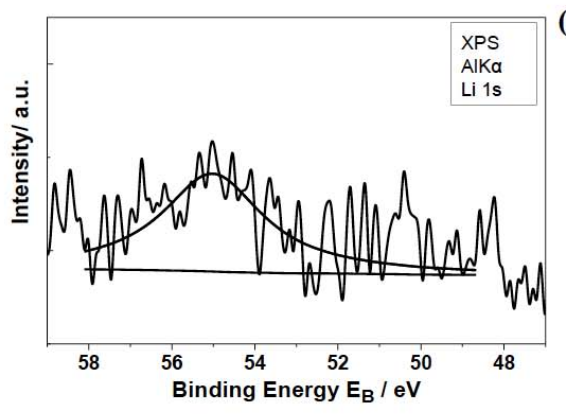

(b)

(c)

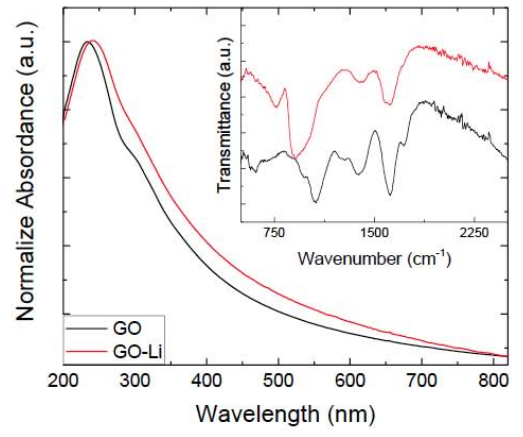

Figure 3: (a) Deconvoluted C1s peak of GO sample, (b) Li1s peak of GO-Li, (c) UV-vis absorption spectra of GO and GO-Li aqueous suspensions. The inline diagram shows the IR permeation spectra (using the attenuated total reflection technique ATR) for the same samples. 
Table 3: The Ratio of the Intensities of $D$ to $G$ Peak as well the Intensity $2 D$ to $D+G$ Peak for the Various GRM Coatings

\begin{tabular}{|c|c|c|}
\hline Sample & I(D)/I(G) & I(2D/D+G) \\
\hline \hline GO & $0.91 \pm 0.03$ & $0.72 \pm 0.1$ \\
\hline rGO & $1.03 \pm 0.02$ & $0.75 \pm 0.04$ \\
\hline GO-Li & $0.94 \pm 0.03$ & $0.74 \pm 0.1$ \\
\hline rGO-Li & $1.03 \pm 0.02$ & $0.77 \pm 0.08$ \\
\hline
\end{tabular}

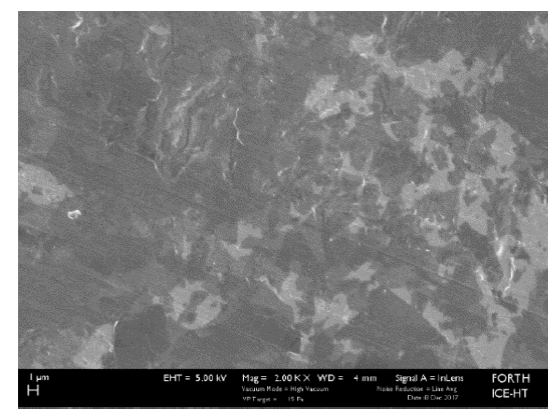

(a)

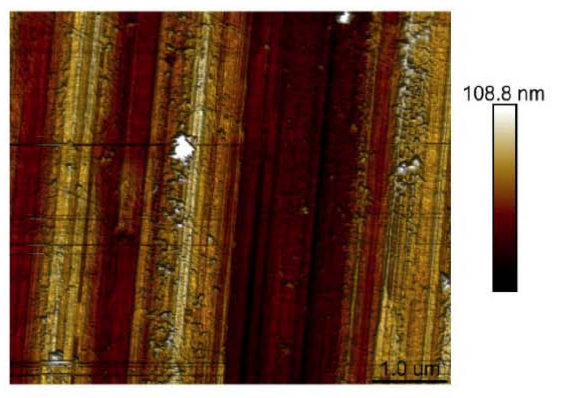

(c)

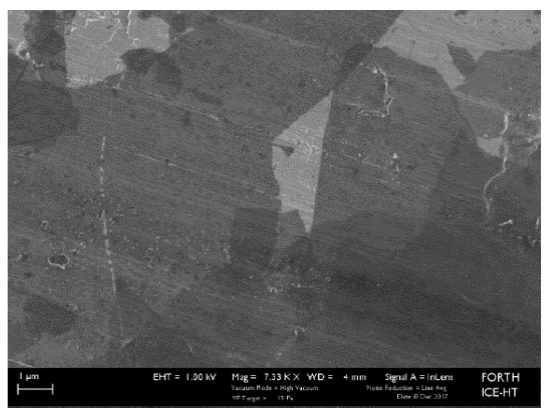

(b)

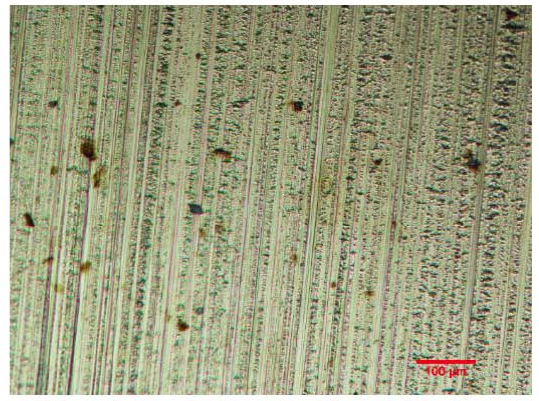

(d)

Figure 4: (a), (b) SEM images (the scale bar is at $1 \mu \mathrm{m}$ ), (c) AFM topography 3D-image (the scale bar is at $1 \mu \mathrm{m}$ ) and (d) OM image (the scale bar is at $1 \mu \mathrm{m}$ ) for the case of $\mathrm{GO}$ coated on bare $\mathrm{Al}_{1000}$ substrate foil.

In Figure S10, the G-peak intensity Raman maps are presented. As it seems, all the produced samples are fully covered. Any difference in the intensity values observed among the samples and the different areas of each specimen is attributed to the fact that a different GO derivative type of GRM is applied on the aluminum substrate foil (Al). Furthermore, morphological differences between different specimens are observed by OM, SEM, and AFM (Figure 4). In fact, the GO seems to follow the surface morphology fully, and the characteristic rolling lines emanated from the production process are clearly evident.

\subsection{Corrosion Measurements}

Corrosion measurements were carried out on the completion of sample characterization using sulfuric acid $\left(\mathrm{H}_{2} \mathrm{SO}_{4}, 0.5 \mathrm{M}\right)$ and lithium perchlorate $\left(\mathrm{LiClO}_{4}, 1 \mathrm{M}\right)$ as corrosion electrolytes. Sulfuric acid is a widespread electrolyte [49] often chosen for corrosion tests. At the same time, lithium perchlorate is an ideal electrolyte for studying the behavior of the samples in a Li salt environment [50], such as that encountered in a Li-ion battery.
In both cases, the anodic corrosion of $\mathrm{Al}$ in the liquid electrolytes can be summarized in two steps. First, the formation of $\mathrm{Al}^{3+}$ occurs in the electrochemical process [5154]:

$A l_{(S)} \rightarrow A l^{3+}+3 e^{-}$

Subsequently, the unstable $\mathrm{Al}^{3+}$ tends to form complexes with ions or solvent molecules $(X)$ :

$A l^{3+}+X \rightarrow A l X_{n}^{(3-n)+}(1 \leq n \leq 3)$

These reactions occur simultaneously with the effect of complex and interdependent factors, such as the composition of the electrolyte, the applied anodic voltage, etc. In addition, they are significantly affected by the coverage of the metallic surface with a protective layer.

The corrosion rate (CR) calculation is based on Faraday's Law, according to the following expression [55]:

$C R=K \cdot E W \frac{I_{\text {corr }}}{\rho}$ 
where $K$ is the corrosion constant $\left(327,2 \mathrm{~mm} \mathrm{Kg} \mathrm{A}^{-1} \mathrm{~m}^{-1} \mathrm{yr}^{-1}\right)$, $E W$ is the equivalent weight, and $\rho$ the density of the $\mathrm{Al}$, respectively.

In addition, for the evaluation of the corrosion inhibition efficiency $\eta$, the following expression is used [34]:

$\eta=\frac{I_{\text {corr,sub }}-I_{\text {corr,coat }}}{I_{\text {corr sub }}}$

While, the polarization resistance $R_{p}$ is estimated based on the Stern-Geary equation[56], using the anodic $\left(b_{a}\right)$ and cathodic $\left(b_{c}\right)$ slopes of the Tafel plots:

$$
R_{p}=\frac{b_{a} b_{c}}{2,303 \cdot I_{\text {corr }}\left(b_{a}+b_{c}\right)}
$$

Figures 5 and 6 show the corresponding potentiodynamic polarization curves for all the examined samples (commercial and prototypes) for the $\mathrm{H}_{2} \mathrm{SO}_{4}$ and $\mathrm{LiClO}_{4}$ as corrosion electrolytes, respectively. Similarly, in Tables 2 and 3, the corrosion rates $(C R)$, the corrosion inhibition efficiency $(n)$, the polarization resistance $(R s)$ as well the corrosion current density $\left(I_{\text {corr }}\right)$, and the corrosion potential $\left(E_{\text {corr }}\right)$ are presented.

According to the potentiodynamic polarization curves of Figure $\mathbf{5}$, the $E_{\text {corr }}$ of all coated Al samples is shifted towards more positive potentials compared to the untreated aluminum foils. Such a shift implements that all coated samples appear to have a stronger resistance to corrosion [34, 57]. In addition, all coated samples show a reduction of $I_{\text {corr }}$ values compared to bare $\mathrm{Al}$, where the $\mathrm{Al}$ samples coated with GOs are more pronounced. A summary of all the results presented in Figure $\mathbf{5}$ is given in Table $\mathbf{4}$ below.

It seems that all Al foils coated with graphene materials act as a protective barrier, with the results consistent with those in literature $[12,34,58,59]$. For all coated samples, the $\eta$ values increase significantly compared to bare foil. Such behavior is even greater for the oxide-coated and modified graphene oxides (GOs) samples, reaching up to $96.1 \%$ for the rGO-coated sample. Such a performance is probably attributed to the packing of the GOs sheets together as a result of the coating process.
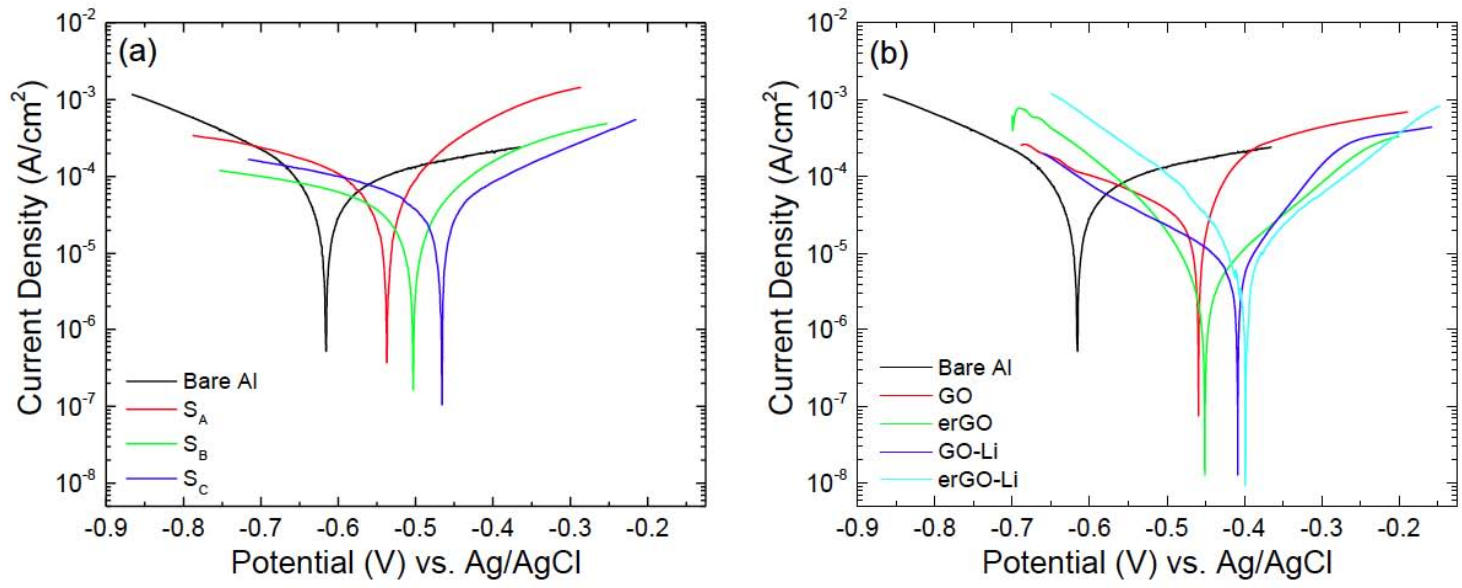

Figure 5: Tafel curves obtained using $\mathrm{H}_{2} \mathrm{SO}_{4} 0.5 \mathrm{M}$ as corrosion electrolyte for (a) the commercially available materials and (b) for the GRMs (GO, rGO, GO-Li and rGO-Li) applied on the bare Al foil.
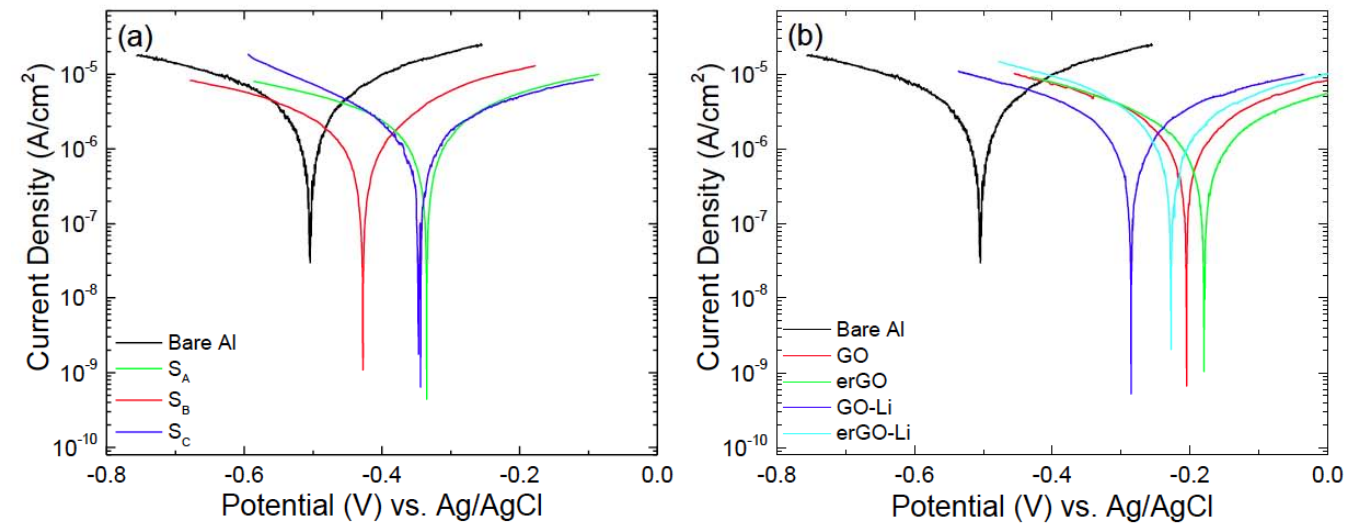

Figure 6: Tafel curves obtained using $\mathrm{LiClO}_{4} 1 \mathrm{M}$ as corrosion electrolyte for (a) the commercial available materials and, (b) (c) for the GRMs (GO, rGO, GO-Li and rGO-Li) applied on bare Al substrate foil. 
Table 4: Corrosion Results Obtained for all Samples Examined for the Case of $\mathrm{H}^{2} \mathrm{SO}^{4} 0.5 \mathrm{M}$

\begin{tabular}{|c|c|c|c|c|c|c|c|}
\hline Sample & $\begin{array}{l}\text { Ecorr } \\
(\mathrm{mV})\end{array}$ & $\begin{array}{c}\text { Icorr } \\
\left(\mu \mathrm{A} \mathrm{cm}{ }^{-2}\right)\end{array}$ & $\begin{array}{c}\text { bc } \\
\left(V \operatorname{dec}^{-1}\right)\end{array}$ & $\begin{array}{c}\text { ba } \\
\left(V \operatorname{dec}^{-1}\right)\end{array}$ & $\begin{array}{c}\mathrm{CR} \\
\left(\mathrm{mm} \mathrm{yr}^{-1}\right)\end{array}$ & $\underset{\left(\Omega \mathrm{cm}^{-2}\right)}{\mathbf{R p}}$ & $\begin{array}{c}\eta \\
(\%)\end{array}$ \\
\hline Bare Al & -615.5 & 117.9 & 0.259 & 0.814 & 1.286 & 724 & 0 \\
\hline$S_{A}$ & -537.1 & 71.7 & 0.293 & 0.149 & 0.782 & 599 & $39.2^{*}$ \\
\hline $\mathrm{S}_{\mathrm{B}}$ & -503.0 & 45.3 & 0.593 & 0.191 & 0.494 & 1385 & $61.6^{*}$ \\
\hline $\mathrm{S}_{\mathrm{C}}$ & -465.8 & 44.0 & 0.389 & 0.219 & 0.479 & 1385 & $62.7^{*}$ \\
\hline GO & -459.3 & 42.9 & 0.369 & 0.097 & 0.468 & 778 & 63.6 \\
\hline rGo & -451.0 & 4.6 & 0.115 & 0.120 & 0.050 & 5566 & 96.1 \\
\hline GO-Li & -408.4 & 7.8 & 0.192 & 0.086 & 0.085 & 3303 & 93.4 \\
\hline rGO-Li & -398.7 & 11.6 & 0.112 & 0.137 & 0.126 & 2309 & 90.2 \\
\hline
\end{tabular}

*These values are obtained by using as a reference the bare Al.

Table 5: Corrosion Results Obtained for all Samples Examined for the Case of $\mathrm{LiClO}_{4} 1 \mathrm{M}$

\begin{tabular}{|c|c|c|c|c|c|c|c|}
\hline Sample & $\begin{array}{l}E_{\text {corr }} \\
(\mathrm{mV})\end{array}$ & $\begin{array}{c}I_{\text {corr }} \\
\left(\mu \mathrm{A} \mathrm{cm}^{-2}\right)\end{array}$ & $\begin{array}{c}\text { bc } \\
\left(V \operatorname{dec}^{-1}\right)\end{array}$ & $\begin{array}{c}\text { ba } \\
\left(V \operatorname{dec}^{-1}\right)\end{array}$ & $\begin{array}{c}C R \\
\left(m m y^{-1}\right)\end{array}$ & $\begin{array}{c}\mathbf{R p} \\
\left(\Omega \mathrm{cm}^{-2}\right)\end{array}$ & $\begin{array}{c}\eta \\
(\%)\end{array}$ \\
\hline Bare Al & -505.4 & 7.38 & 0.681 & 0.479 & 0.0805 & 16567 & - \\
\hline $\mathrm{S}_{\mathrm{A}}$ & -427.8 & 2.87 & 0.545 & 0.362 & 0.0313 & 32925 & $61.1^{*}$ \\
\hline $\mathrm{S}_{\mathrm{B}}$ & -335.1 & 2.97 & 0.579 & 0.481 & 0.0324 & 38362 & $59.7^{*}$ \\
\hline $\mathrm{S}_{\mathrm{c}}$ & -343.8 & 2.53 & 0.291 & 0.479 & 0.0276 & 30995 & $65.7^{\star}$ \\
\hline GO & -204.7 & 2.19 & 0.363 & 0.340 & 0.0239 & 34812 & 70.3 \\
\hline rGo & -179.5 & 1.24 & 0.291 & 0.262 & 0.0135 & 48360 & 83.2 \\
\hline GO-Li & -285.5 & 2.31 & 0.442 & 0.380 & 0.0252 & 38414 & 68.7 \\
\hline rGO-Li & -227.4 & 2.42 & 0.353 & 0.350 & 0.0264 & 31569 & 67.3 \\
\hline
\end{tabular}

"These values are obtained by using as a reference the bare Al.

As for the commercially available samples, the sample with the lowest $C R$ value is $S_{c}$. It is noted that the values obtained cannot be completely compared due to differences in the initial aluminum substrate foil. However, they are higher than the GOs coatings produced in this work, which implies that the latter exhibit a superior anti-corrosion performance vis-àvis the current commercial products. As explained earlier, the examined commercial coatings contain high vacancies; thus, they are prone to pitting [24]. In fact, the corrosion rate for commercial samples seems to decrease as the surface coverage increases.

In Figure 6, the corresponding potentiodynamic polarization curves for $\mathrm{LiClO}_{4}$ as a corrosion electrolyte are presented. The results of the analysis of these curves are summarized in Table 3, where $C R, \eta$, and $R_{p}$ were calculated, respectively, and the values for the $E_{c o r r}$ and $I_{\text {corr }}$ measurements of the samples were also recorded. The shift of the curves of the coated specimens to zero values is also evident in this case, indicating greater resistance to corrosion than the bare foils.

Based on the results of Table $\mathbf{5}$, it is evident that the graphene materials employed are also acting as anticorrosion barriers. An increase in corrosion protection is observed for GOs samples, with the highest value $(83.2 \%)$ obtained for the case of $\mathrm{rGO}$, which can be again attributed to the higher packaging of the rGO layers on the completion of the reduction process [47].
On the other hand, Li functionalized GOs show higher corrosion resistance in the aqueous electrolyte solution. However, the recorded $I_{\text {corr }}$ values are higher compared to non-functionalized GOs. Such behavior implies that a reaction between the Li-functional groups with the ions of the non-aqueous electrolyte solution takes place. As for the commercially available samples, their performance is similar to those obtained with $\mathrm{H}_{2} \mathrm{SO}_{4}$, where $\mathrm{S}_{\mathrm{C}}$ has the lowest $\mathrm{CR}$.

The corrosion measurements with $\mathrm{LiClO}_{4} 1 \mathrm{M}$ confirmed again that the graphene oxide-based coatings on Al foils produced in this work have clearly better anti-corrosion performance. This behavior confirms the fact that the continuity of the protective layer is one of the most critical parameters. As postulated elsewhere [51], the coating of the cathode electrode appears to be beneficial in increasing other parameters such as the charge-discharge cycles and providing good electrochemical performance. Thus, it can help the Al substrates be more stable as a cathode electrode and increase their service life.

\section{CONCLUSIONS}

$\mathrm{GO}, \mathrm{rGO}$, and functionalized GOs were coated on Al foils to study the degree of corrosion they can provide in aqueous (0.5 $\left.\mathrm{M} \mathrm{H}_{2} \mathrm{SO}_{4}\right)$ and non-aqueous (1 $\mathrm{M} \mathrm{LiClO}_{4}$ ) corrosive environments. In addition, commercial GRM coated Al foils, 
which are already used as electrodes in LIBs, were tested in parallel and under the same corrosive environments. From the morphological and spectroscopic characterization methods employed, it is evident that the GO coated samples provide a thin homogeneous coating up to $6 \mathrm{~nm}$, in contrast to the commercial coated specimens investigated here, in which the graphitic materials form an inhomogeneous coating up to few $\mu \mathrm{m}$, that contains pits and gaps in various locations.

The corrosion behavior of the specimens was evaluated electrochemically by measuring the corrosion current density and potential and by subsequently estimating on both corrosive environments the corrosion rate, the polarization resistance, and protection efficiency factor. From the results obtained, it appeared that all coated specimens provided lower $C R$ and higher $R s$ in comparison to the bare Al foil. However, the functionalized GOs showed better characteristics as a consequence of their coating on the $\mathrm{Al}$ foil, providing $\eta$ values greater than $90 \%$ in $\mathrm{H}_{2} \mathrm{SO}_{4}$ and $80 \%$ in $\mathrm{LiClO}_{4}$, respectively. All these results substantiate our initial premise that functionalized GOs can be used as corrosion protection coatings of $\mathrm{Al}$ foils in LIBs applications.

\section{ASSOCIATED CONTENT}

\section{Supporting Information}

Further experimental data and explanations are given upon S1: Corrosion measurements setup, S2: Spectroscopic data, S3: OM, SEM AFM, and XRD analysis on commercial Al foil coated with GRMs, S4: Analysis of coatings with GO and its derivatives.

\section{Author Contributions}

The manuscript was written through the contributions of all authors. All authors have approved the final version of the manuscript.

\section{ACKNOWLEDGEMENTS}

This project has received funding from the European Union's Horizon 2020 research and innovation program under grant agreements graphene Core 2 (785219) and Graphene Core 3 (881603). SYMETAL S.A. (Greece) is thanked for providing the Al specimens.

\section{SUPPLEMENTAL MATERIALS}

The supplemental materials can be downloaded from the journal website along with the article.

\section{REFERENCES}

[1] Álvarez-Fraga L, Rubio-Zuazo J, Jiménez-Villacorta F, ClimentPascual E, Ramírez-Jiménez R, Prieto $C$, de Andrés A. Oxidation Mechanisms of Copper under Graphene: The Role of Oxygen Encapsulation. Chem Mater 2017; 29(7): 3257-3264. https://doi.org/10.1021/acs.chemmater.7b00554
Lytle DA, Nadagouda MN. A comprehensive investigation of copper pitting corrosion in a drinking water distribution system. Corrosion Science 2010; 52(6): 1927-1938.

\section{https://doi.org/10.1016/i.corsci.2010.02.013}

[3] Björkbacka A, Hosseinpour S, Johnson M, Leygraf C, Jonsson M. Radiation-induced corrosion of copper for spent nuclear fuel storage. Radiation Physics and Chemistry 2013; 92: 80-86. https://doi.org/10.1016/j.radphyschem.2013.06.033

[4] Böhm S. Graphene against corrosion, Nat Nanotechnol 2014; 9: 741. https://doi.org/10.1038/nnano.2014.220

[5] Koch JVG, Thompson N, Moghissi O, Gould M, Payer J. Internationa Measures of Prevention, Application and Economics of Corrosion Technology (IMPACT), in: G. Jacobson (Ed.) NACE International 2016

[6] Kuznetsova A, Yates JT, Zhou G, Yang JC, Chen X. Making a Superior Oxide Corrosion Passivation Layer on Aluminum Using Ozone. Langmuir 2001; 17(7): 2146-2152.

https://doi.org/10.1021/la001300x

[7] Hu J-M, Liu L, Zhang J-Q, Cao C-N. Electrodeposition of silane films on aluminum alloys for corrosion protection. Progress in Organic Coatings 2007; 58(4): 265-271.

https://doi.org/10.1016/j.porgcoat.2006.11.008

[8] Chen S, Brown L, Levendorf M, Cai W, Ju S-Y, Edgeworth J, Li X Magnuson CW, Velamakanni A, Piner RD, Kang J, Park J, Ruoff RS. Oxidation Resistance of Graphene-Coated $\mathrm{Cu}$ and $\mathrm{Cu} / \mathrm{Ni}$ Alloy. ACS Nano $2011 ; 5(2)$ : 1321-1327. https://doi.org/10.1021/nn103028d

Cho E, Mun J, Chae OB, Kwon OM, Kim H-T, Ryu JH, Kim YG, Oh SM. Corrosion/passivation of aluminum current collector in bis(fluorosulfonyl)imide-based ionic liquid for lithium-ion batteries Electrochemistry Communications 2012; 22: 1-3. https://doi.org/10.1016/i.elecom.2012.05.018

[10] Gnedenkov SV, Sinebryukhov SL, Mashtalyar DV, Egorkin VS, Sidorova MV, Gnedenkov AS. Composite polymer-containing protective coatings on magnesium alloy MA8. Corrosion Science 2014; 85: 52-59.

https://doi.org/10.1016/j.corsci.2014.03.035

[11] Yang XF, Tallman DE, Gelling VJ, Bierwagen GP, Kasten LS, Berg J. Use of a sol-gel conversion coating for aluminum corrosion protection. Surface and Coatings Technology 2001; 140(1): 44-50. https://doi.org/10.1016/S0257-8972(01)01002-7

[12] Prasai D, Tuberquia JC, Harl RR, Jennings GK, Bolotin KI. Graphene: corrosion-inhibiting Coating. ACS Nano 2012; 6(2): 1102-1108. https://doi.org/10.1021/nn203507y

[13] Nine MJ, Cole MA, Tran DNH, Losic D. Graphene: a multipurpose material for protective coatings. Journal of Materials Chemistry A 2015; 3(24): 12580-12602.

https://doi.org/10.1039/C5TA01010A

[14] Calabrese L, Khaskoussi A, Proverbio E. Wettability and AntiCorrosion Performances of Carbon Nanotube-Silane Composite Coatings. Fibers 2020; 8(9): 57 https://doi.org/10.3390/fib8090057

[15] Pourhashem S, Ghasemy E, Rashidi A, Vaezi MR. A review on application of carbon nanostructures as nanofiller in corrosionresistant organic coatings. Journal of Coatings Technology and Research 2020; 17(1): 19-55 https://doi.org/10.1007/s11998-019-00275-6

[16] Topsakal M, Şahin H, Ciraci S. Graphene coatings: An efficient protection from oxidation. Phys Rev B 2012; 85(15): 155445. https://doi.org/10.1103/PhysRevB.85.155445

[17] Ding R, Li W, Wang X, Gui T, Li B, Han P, Tian H, Liu A, Wang X, Liu X, Gao X, Wang W, Song L. A brief review of corrosion protective films and coatings based on graphene and graphene oxide. Journal of Alloys and Compounds 2018; 764: 1039-1055. https://doi.org/10.1016/j.jallcom.2018.06.133

[18] Berry V. Impermeability of graphene and its applications Carbon 2013; 62: 1-10.

https://doi.org/10.1016/j.carbon.2013.05.052

[19] Lanza JHYJYSFHHDM. A Review on the use of graphene as Protective Coating against Corrosion. Annals of Materials Science \& Engineering 2014; 1(3): 1-7.

[20] Singh Raman RK, Tiwari A. Graphene: The Thinnest Known Coating for Corrosion Protection. Jom 2014; 66(4): 637-642. https://doi.org/10.1007/s11837-014-0921-3

[21] Robert VD, Vikas P, Justin LA, Jeffrey PA, Ganapati DY, Sarbajit B. Hybrid nanostructured coatings for corrosion protection of base 
metals: a sustainability perspective. Materials Research Express 2015; 2(3): 032001. https://doi.org/10.1088/2053-1591/2/3/032001

[22] Kirkland NT, Schiller T, Medhekar N, Birbilis N. Exploring graphene as a corrosion protection barrier. Corrosion Science 2012; 56: 1-4. https://doi.org/10.1016/j.corsci.2011.12.003

[23] Singh Raman RK, Chakraborty Banerjee P, Lobo DE, Gullapalli H, Sumandasa M, Kumar A, Choudhary L, Tkacz R, Ajayan PM, Majumder M. Protecting copper from electrochemical degradation by graphene coating. Carbon 2012; 50(11): 4040-4045.

\section{https://doi.org/10.1016/j.carbon.2012.04.048}

[24] Schriver M, Regan W, Gannett WJ, Zaniewski AM, Crommie MF, Zettl A. Graphene as a Long-Term Metal Oxidation Barrier: Worse Than Nothing. ACS Nano 2013; 7(7): 5763-5768. https://doi.org/10.1021/nn4014356

[25] Zhou F, Li Z, Shenoy GJ, Li L, Liu H. Enhanced Room-Temperature Corrosion of Copper in the Presence of Graphene. ACS Nano 2013; 7(8): 6939-6947.

https://doi.org/10.1021/nn402150t

[26] Mišković-Stanković V, Jevremović I, Jung I, Rhee K. Electrochemical study of corrosion behavior of graphene coatings on copper and aluminum in a chloride solution. Carbon 2014; 75: 335-344.

\section{https://doi.org/10.1016/i.carbon.2014.04.012}

[27] Merisalu M, Kahro T, Kozlova J, Niilisk A, Nikolajev A, Marandi M, Floren A, Alles H, Sammelselg V. Graphene-polypyrrole thin hybrid corrosion-resistant coatings for copper. Synthetic Metals 2015; 200: 16-23. https://doi.org/10.1016/i.synthmet.2014.12.024

[28] Maeztu JD, Rivero PJ, Berlanga C, Bastidas DM, Palacio JF, Rodriguez R. Effect of graphene oxide and fluorinated polymeric chains incorporated in a multilayered sol-gel nano-coating for the design of corrosion-resistant and hydrophobic surfaces. Applied Surface Science 2017; 419: 138-149.

https://doi.org/10.1016/j.apsusc.2017.05.043

[29] Zheng Z, Liu Y, Bai Y, Zhang J, Han Z, Ren L. Fabrication of biomimetic hydrophobic patterned graphene surface with eco-friendly anti-corrosion properties for Al alloy. Colloids and Surfaces A: Physicochemical and Engineering Aspects 2016; 500: 64-71.

https://doi.org/10.1016/j.colsurfa.2016.04.008

[30] Boccaccini AR, Roether JA, Thomas BJC, Shaffer MSP, Chavez E, Stoll E, Minay EJ. The Electrophoretic Deposition of Inorganic Nanoscaled Materials: A Review. Journal of the Ceramic Society of Japan 2006; 114(1325): 1-14.

https://doi.org/10.2109/jcersj.114.1

[31] Chavez-Valdez A, Shaffer MSP, Boccaccini AR. Applications of Graphene Electrophoretic Deposition. A Review. The Journal of Physical Chemistry B 2013; 117(6): 1502-1515. https://doi.org/10.1021/ip3064917

[32] Diba M, Fam DWH, Boccaccini AR, Shaffer MSP. Electrophoretic deposition of graphene-related materials: A review of the fundamentals. Progress in Materials Science 2016; 82: 83-117. https://doi.org/10.1016/j.pmatsci.2016.03.002

[33] Singh BP, Jena BK, Bhattacharjee S, Besra L. Development of oxidation and corrosion resistance hydrophobic graphene oxidepolymer composite coating on copper. Surface and Coatings Technology 2013; 232: 475-481.

https://doi.org/10.1016/j.surfcoat.2013.06.004

[34] Singh BP, Nayak S, Nanda KK, Jena BK, Bhattacharjee S, Besra L. The production of a corrosion-resistant graphene reinforced composite coating on copper by electrophoretic deposition. Carbon 2013; 61: 47-56.

https://doi.org/10.1016/j.carbon.2013.04.063

[35] Ding S, Xiang T, Li C, Zheng S, Wang J, Zhang M, Dong C, Chan W. Fabrication of self-cleaning super-hydrophobic nickel/graphene hybrid film with improved corrosion resistance on mild steel. Mater Des 2017; 117: 280-288.

https://doi.org/10.1016/j.matdes.2016.12.084

[36] Park JH, Park JM. Electrophoretic deposition of graphene oxide on mild carbon steel for anti-corrosion application. Surface and Coatings Technology 2014; 254: 167-174. https://doi.org/10.1016/i.surfcoat.2014.06.007

[37] Ferrari AC, Bonaccorso F, Fal'ko V, Novoselov KS, Roche S, Bøggild $\mathrm{P}$, et al. Science and technology roadmap for graphene, related twodimensional crystals, and hybrid systems. Nanoscale 2015; 7(11): 4598-4810. https://doi.org/10.1039/C4NR01600A

[38] Kovtyukhova NI, Ollivier PJ, Martin BR, Mallouk TE, Chizhik SA, Buzaneva EV, Gorchinskiy AD. Layer-by-Layer Assembly of Ultrathin
Composite Films from Micron-Sized Graphite Oxide Sheets and Polycations. Chemistry of Materials 1999; 11(3): 771-778. https://doi.org/10.1021/cm981085u

[39] Zhou M, Wang Y, Zhai Y, Zhai J, Ren W, Wang F, Dong S. Controlled Synthesis of Large-Area and Patterned Electrochemically Reduced Graphene Oxide Films. Chemistry-A European Journal 2009; 15(25): 6116-6120. https://doi.org/10.1002/chem.200900596

[40] Ferrari AC, Meyer JC, Scardaci V, Casiraghi C, Lazzeri M, Mauri F, Piscanec S, Jiang D, Novoselov KS, Roth S, Geim AK. Raman Spectrum of Graphene and Graphene Layers. Phys Rev Lett 2006; 97(18): 187401.

https://doi.org/10.1103/PhysRevLett.97.187401

[41] Beams R, Cançado LG, Novotny L. Raman characterization of defects and dopants in graphene. Journal of Physics: Condensed Matter 2015; 27(8): 083002.

https://doi.org/10.1088/0953-8984/27/8/083002

[42] Surekha K, Murty BS, Rao KP. Microstructural characterization and corrosion behavior of multipass friction stir processed AA2219 aluminium alloy. Surface and Coatings Technology 2008; 202(17): 4057-4068.

https://doi.org/10.1016/j.surfcoat.2008.02.001

[43] Yang D, Velamakanni A, Bozoklu G, Park S, Stoller M, Piner RD, Stankovich S, Jung I, Field DA, Ventrice CA, Ruoff RS. Chemical analysis of graphene oxide films after heat and chemical treatments by X-ray photoelectron and Micro-Raman spectroscopy. Carbon 2009; 47(1): 145-152.

https://doi.org/10.1016/i.carbon.2008.09.045

[44] Sygellou L, Paterakis G, Galiotis C, Tasis D. Work Function Tuning of Reduced Graphene Oxide Thin Films. The Journal of Physical Chemistry C 2016; 120(1): 281-290.

https://doi.org/10.1021/acs.jpcc.5b09234

[45] Lellala K, Namratha K, Byrappa K. Ultrasonication assisted mild solvothermal synthesis and morphology study of few-layered graphene by colloidal suspensions of pristine graphene oxide. Microporous and Mesoporous Materials 2016; 226(Supplement C): 522-529.

https://doi.org/10.1016/i.micromeso.2016.01.036

[46] Szabó T, Berkesi O, Dékány I. DRIFT study of deuterium-exchanged graphite oxide. Carbon 2005; 43(15): 3186-3189. https://doi.org/10.1016/i.carbon.2005.07.013

[47] Pei S, Cheng H-M. The reduction of graphene oxide. Carbon 2012; 50(9): 3210-3228.

https://doi.org/10.1016/j.carbon.2011.11.010

[48] Moon IK, Lee J, Ruoff RS, Lee H. Reduced graphene oxide by chemical graphitization. Nature Communications 2010; 1(1): 73.

https://doi.org/10.1038/ncomms1067

[49] Chen P, Fang F, Zhang Z, Zhang W, Wang Y. Self-assembled graphene film to enable highly conductive and corrosion-resistant aluminum bipolar plates in fuel cells, International Journal of Hydrogen Energy 2017.

https://doi.org/10.1016/j.ijhydene.2017.03.214

[50] Zhang SS, Jow TR. Aluminum corrosion in electrolyte of Li-ion battery. Journal of Power Sources 2002; 109(2): 458-464. https://doi.org/10.1016/S0378-7753(02)00110-6

[51] Wang M, Tang M, Chen S, Ci H, Wang K, Shi L, Lin L, Ren H, Shan J, Gao P, Liu Z, Peng H. Graphene-Armored Aluminum Foil with Enhanced Anticorrosion Performance as Current Collectors for Lithium-Ion Battery. Advanced Materials 2017; 29(47): 1703882. https://doi.org/10.1002/adma.201703882

[52] Zhang S, Jow T. Aluminum corrosion in electrolyte of Li-ion battery. Journal of Power Sources 2002; 109(2): 458-464. https://doi.org/10.1016/S0378-7753(02)00110-6

[53] Hikku GS, Jeyasubramanian K, Venugopal A, Ghosh R. Corrosion resistance behaviour of graphene/polyvinyl alcohol nanocomposite coating for aluminium-2219 alloy. Journal of Alloys and Compounds 2017; 716: 259-269. https://doi.org/10.1016/j.jallcom.2017.04.324

[54] Kawakita J, Kobayashi K. Anodic oxidation behaviour of aluminium in propylene carbonate. Journal of Power Sources 2000; 90(2): 182-187. https://doi.org/10.1016/S0378-7753(00)00408-0

[55] AG. 89, Standard Practice for Calculation of Corrosion Rates and Related Information from Electrochemical Measurements, West Conshohocken, PA 19428-2959, United States, 1999.

[56] Roberge PR. Handbook of corrosion engineering, McGraw-Hill 2000.

[57] Chen P, Fang F, Zhang Z, Zhang W, Wang Y. Self-assembled graphene film to enable highly conductive and corrosion-resistant 
Journal of Coating Science and Technology, 2021, Volume 8

aluminum bipolar plates in fuel cells. International Journal of Hydrogen Energy 2017; 42(17): 12593-12600. https://doi.org/10.1016/j.ijhydene.2017.03.214

$[58]$

Dun Y, Zuo Y. Preparation and characterization of a GPTMS/graphene coating on AA-2024 alloy. Applied Surface Science 2017; 416: 492-502.

https://doi.org/10.1016/i.apsusc.2017.04.116
[59] Liu J, Hua L, Li S, Yu M. Graphene dip coatings: An effective anticorrosion barrier on aluminum. Applied Surface Science 2015; 327 241-245.

https://doi.org/10.1016/i.apsusc.2014.11.187

(C) 2021 Paterakis et al.; Licensee Lifescience Global.

This is an open access article licensed under the terms of the Creative Commons Attribution License (http://creativecommons.org/licenses/by/4.0/) which permits unrestricted use, distribution and reproduction in any medium, provided the work is properly cited. 